

Janina Duszyńska

Sylwia Walczak

\title{
Wpływ ćwiczeń z kinezjologii edukacyjnej na skuteczność uczenia się słownictwa na lekcjach języka obcego*
}

DOI: http://dx.doi.org/10.12775/PBE.2013.023

\section{Podstawy teoretyczne kinezjologii edukacyjnej}

Kinezjologia edukacyjna, jako nowy kierunek w terapii rozwoju psychomotorycznego dziecka, pochodzi od greckich słów kinematos, czyli 'ruch', i logos - 'mowa' - oraz od łacińskiego słowa educatio - 'edukacja', 'wychowanie', 'wykształcenie' (Grzywniak, 2006, s. 22). Swoim zakresem obejmuje wiedzę o ruchu i możliwościach stymulacji różnych funkcji psychicznych przy wykorzystaniu naturalnych ruchów całego ciała (Grzywniak, 2006, s. 22). Podstawową metodą kinezjologii edukacyjnej jest Gimnastyka Mózgu opracowana przez Dennisonów. Polega ona na systematycznym stosowaniu odpowiednich ćwiczeń, mających na celu pobudzić różne obszary mózgu, polepszyć koncentrację i regulować emocje. Ćwiczenia te odnoszą się do koordynacji ruchowej całego ciała, koordynacji ruchowo-wzrokowej, koordynacji zmysłów słuchu, wzro$\mathrm{ku}$, czucia proprioceptywnego, równowagi, planowania ruchu, poruszania się

\footnotetext{
${ }^{*}$ Przypisy końcowe w tym artykule zawierają uwagi recenzenta (przyp. - red.).
} 
w przestrzeni, umiejętności przewidywania i myślenia. Gimnastyka Mózgu integruje pracę centralnego układu nerwowego, jak również wpływa na polepszenie procesu uczenia się i uzyskanie równowagi emocjonalnej (Grzywniak, 2006, s. 24). Regularne powtarzanie tych samych ćwiczeń przyczynia się do formowania i zwielokrotniania nowych połączeń między komórkami nerwowymi, co w efekcie zwiększa plastyczność mózgu (Grzywniak, 2006, s. 24).

Do głównych założeń teoretycznych kinezjologii edukacyjnej należą:

1. Dwie półkule mózgu człowieka specjalizują się w określonych funkcjach: lewa półkula zwana jest logiczną, a prawa - odruchową. Dla prawidłowego funkcjonowania konieczna jest integracja działania obu półkul. Zadaniem ćwiczeń z kinezjologii edukacyjnej jest spowodowanie powstania połączeń pomiędzy dwiema półkulami mózgu, co w efekcie prowadzi do całościowego, zintegrowanego myślenia. Im więcej połączeń, tym szybszy przebieg procesów myślowych.

2. Ludzi można podzielić na takich, u których dominuje lewa lub prawa półkula mózgowa. To, która półkula dominuje u człowieka, ma wpływ na indywidualny styl poznawczy, charakteryzujący sposób, w jaki odbiera on rzeczywistość i w niej działa. W warunkach stresu przepływ bodźców w półkuli niedominującej zostaje zablokowany, co ma niekorzystny wpływ na możliwości myślenia i działania człowieka (Grabowska, 2008, s. 43-45).

Dennisonowie podzielili ćwiczenia na następujące grupy:

a) ćwiczenia lateralne, zwiększające liczbę połączeń nerwowych pomiędzy lewą i prawą półkulą, co sprzyja lepszej integracji myśli, ruchu i koordynacji całego ciała,

b) ćwiczenia rozciągające i wydłużające mięśnie, mające na celu zminimalizować wpływ stresu i poprawić koncentrację uwagi,

c) ćwiczenia energetyzujące ciało, zapewniające odpowiednią szybkość przesyłanych impulsów nerwowych między komórkami nerwowymi, regulujące odpowiedni rozkład energii w ciele i zwiększające motywację do osiągnięcia celu,

d) ćwiczenia pogłębiające, powodujące wyciszenie i stabilizację emocji (Grzywniak, 2006, s. 27-46).

Kinezjologia edukacyjna jest metodą wspomagającą naturalny rozwój człowieka bez względu na wiek. „Ruch fizyczny od wczesnego niemowlęctwa poprzez całe życie odgrywa ważną rolę w tworzeniu sieci komórek nerwowych, które stanowią fizjologiczną istotę uczenia się" (centrumprogres.pl, dostęp: 14.12.2012). 
Jest to metoda szeroko stosowana przez psychologów i pedagogów. Pomimo pozytywnych opinii na temat kinezjologii edukacyjnej, nie ma zgodności co do pewności jej podstaw naukowych. Anna Grabowska, dokonując oceny założeń teoretycznych i naukowych dokonań Dennisonów, podkreśla, że:

1. Założenia metody Dennisona nie są zgodne ze współczesną wiedzą dotyczącą funkcjonowania mózgu.

2. Większość tez dotyczących wyników rzekomych badań naukowych, na których opiera się metoda, jest fałszywa.

3. Opisy procesów i zasad funkcjonowania mózgu zawarte w publikacjach kinezjologii edukacyjnej nie mają sensu z punktu widzenia naukowego.

4. Dennison najprawdopodobniej nigdy nie prowadził badań naukowych nad wpływem proponowanych przez niego ćwiczeń na procesy zachodzące w mózgu oraz na wyniki uczenia się.

5. Niektóre proponowane przez niego ćwiczenia ruchowe mogą przynosić pozytywne skutki, zwłaszcza w zakresie poprawy funkcji ruchowych i wzrokowo - motorycznych (Grabowska, 2008, s. 51)1.

Tak odmienne spojrzenie na problematykę kinezjologii edukacyjnej skłoniło nas do podjęcia badania nad skutecznością opisanej metody. Jego wyniki przedstawiamy w niniejszym artykule.

\section{Założenia metodologiczne badania}

Badanie zostało przeprowadzone w strategii ilościowej, w schemacie eksperymentu laboratoryjnego (odmiana jednoczynnikowa). Mieści się ono w typie badań praktycznych, weryfikacyjnych. Celem badania było sprawdzenie wpływu ćwiczeń z kinezjologii edukacyjnej na skuteczność uczenia się słownictwa na lekcjach języka obcego (szwedzkiego). Określony w ten sposób cel doprowadził do sformułowania następującej hipotezy badawczej: „Studenci, którzy wezmą udział w lekcji języka obcego poprzedzonej ćwiczeniami z kinezjologii edukacyjnej, uzyskają lepsze wyniki w teście poziomu opanowania słownictwa prezentowanego na lekcji niż studenci, którzy uczestniczyli w lekcji języka obcego niepoprzedzonej ćwiczeniami z kinezjologii edukacyjnej".

Uczestnikami eksperymentu była grupa studentów Wydziału Nauk Pedagogicznych UMK, którzy uczyli się języka angielskiego i nie uczyli się języka szwedzkiego. Zgodnie z założeniami eksperymentu laboratoryjnego, zostali oni podzieleni na dwie równoważne grupy liczące po 28 osób. Podział ten został dokonany przez losowy przydział badanych do wariantów zmiennej ustalonej, co zapewniło trafność zewnętrzną badania. Obie grupy wzięły udział w lekcji ję- 
zyka szwedzkiego skupionej na poznaniu 10 słów. W przypadku grupy eksperymentalnej lekcja została poprzedzona serią ćwiczeń z kinezjologii edukacyjnej. Udział w ćwiczeniach stanowił jedyną różnicę pomiędzy grupą eksperymentalną i kontrolną, co daje prawo do wnioskowania przyczynowo-skutkowego. Po dokonaniu tej manipulacji została zmierzona zmienna losowa. Jej wartość stanowiły wyniki testu mierzącego poziom opanowania słownictwa. Był to test typu papier-ołówek. Zarówno test, jak i metody nauczania zastosowane w czasie lekcji języka obcego zostały dostosowane do różnych stylów uczenia się, dzięki czemu wszyscy uczestnicy mieli równe szanse na przyswojenie prezentowanego słownictwa. Trafność wewnętrzna badania została zapewniona dzięki właściwej operacjonalizacji zmiennych, trafnemu przydziałowi badanych do wariantów zmiennej ustalonej oraz trosce o eliminowanie oddziaływania potencjalnych zmiennych zakłócających.

\section{Analiza i interpretacja wyników badania}

W związku z zastosowaniem eksperymentu laboratoryjnego jako metody zbierania danych, analiza wyników badania została oparta na statystycznym modelu analizy danych. Dzięki temu została ustalona istotność statystyczna różnic w badanych grupach.

Pomiar zmiennej losowej został dokonany na poziomie interwałowym. Poszerzyło to znacznie możliwości statystycznej analizy danych.

Tabela 1. Raport ${ }^{2}$

wt

\begin{tabular}{|c|c|c|c|c|}
\hline $\mathbf{p}$ & Średnia & $\mathbf{N}$ & $\begin{array}{c}\text { Odchylenie } \\
\text { standardowe }\end{array}$ & Skośność \\
\hline 1,00 & 16,7857 & 28 & 2,36263 &,- 668 \\
2,00 & 13,9643 & 28 & 2,60316 &,- 636 \\
Ogółem & 15,3750 & 56 & 2,84485 &,- 523 \\
\hline
\end{tabular}

Źródło: badanie własne.

1 - grupa eksperymentalna

2 - grupa kontrolna

Obie badane grupy osiągnęły wysokie wyniki średnie, grupa eksperymentalna osiągnęła wyższy wynik. Rozrzut wartości w obu grupach jest mały. Wystąpiła niewielka lewoskośność rozkładu zmiennych w obu grupach, co świadczy 
o niewielkiej tendencji do wyników wysokich. Rozkład wartości zmiennych zależnych jest zbliżony do rozkładu normalnego w populacji.

\section{Jednoczynnikowa analiza wariancji}

Tabela 2. Test jednorodności wariancji

wt

\begin{tabular}{|c|c|c|c|}
\hline Test Levene'a & df1 & df2 & Istotność \\
\hline, 000 & 1 & 54 &, 995 \\
\hline
\end{tabular}

Źródło: badanie własne.

Test jednorodności wariancji wykazał jej homogeniczność. Wraz z normalnym rozkładem zmiennej losowej pozwoliło to na zastosowanie jednoczynnikowej analizy wariancji Anova. Został również spełniony warunek dotyczący równoliczności badanych grup oraz wystąpiła tylko jedna zmienna ustalona $\mathrm{W}$ analizie.

Tabela 3. Jednoczynnikowa ANOVA ${ }^{4}$

wt

\begin{tabular}{|l|c|c|c|c|c|}
\hline & $\begin{array}{c}\text { Suma } \\
\text { kwadratów }\end{array}$ & df & $\begin{array}{c}\text { Średni } \\
\text { kwadrat }\end{array}$ & F & Istotność \\
\hline Między grupami & 111,446 & 1 & 111,446 & 18,036 & 0,05 \\
Wewnątrz grup & 333,679 & 54 & 6,179 & & \\
Ogółem & 445,125 & 55 & & & \\
\hline
\end{tabular}

Źródło: badanie własne.

Tabela 4. Miara związku

\begin{tabular}{|c|c|c|}
\hline & Eta & Eta kwadrat \\
\hline wt $^{*} \mathrm{p}$ &, 500 &, 250 \\
\hline
\end{tabular}

Źródło: badanie własne.

Wartość Eta kwadrat uniezależnia uzyskany wynik od liczebności próbki.

Uzyskane wyniki pozwalają odrzucić hipotezę zerową o równości średnich wyników w teście w badanych grupach i uznać za prawdziwą hipotezę alternatywną: „Studenci, którzy wezmą udział w lekcji języka obcego poprzedzonej 
ćwiczeniami z kinezjologii edukacyjnej, uzyskają lepsze wyniki w teście poziomu opanowania słownictwa prezentowanego na lekcji niż studenci, którzy uczestniczyli w lekcji języka obcego niepoprzedzonej ćwiczeniami z kinezjologii edukacyjnej”.

\section{Wnioski z badania}

Wystąpiły różnice $\mathrm{w}$ poziomie przyswajania słownictwa języka obcego pomiędzy grupą eksperymentalną i kontrolną na korzyść grupy eksperymentalnej. Przeprowadzona analiza wykazała istotność statystyczną tych różnic. W związku z powyższym można stwierdzić, że jedyna różnica pomiędzy grupami polegająca na udziale uczestników grupy eksperymentalnej w ćwiczeniach z kinezjologii edukacyjnej stanowi przyczynę lepszego przyswojenia słownictwa. Uzyskane wyniki badania pozwalają na rozszerzenie powyższego wniosku na całą populację.

Pomimo braku zgodności co do podstaw naukowych metody kinezjologii edukacyjnej, zaprezentowane powyżej wyniki przeprowadzonego badania potwierdzają jej skuteczność. Chociaż twórca metody Gimnastyki Mózgu nie opierał jej na wynikach własnych badań, punktem wyjścia do jej opracowania było przeprowadzenie syntezy wielu badań, takich jak: Projekt Czytania dr Amsden Malabar, badania dr. Domana i Delacato, dr. Jacque'a i dr. Herra ${ }^{6}$. Powstanie w 1987 r. Fundacji Kinezjologii Edukacyjnej zapoczątkowało badania nad skutecznością tej metody. Między innymi badania przeprowadzone w 1987 r. przez dr Hannaford potwierdziły jej skuteczność (Hannaford, 1995, s. 112) ${ }^{7}$. Następnymi badaniami wartymi przytoczenia są badania przeprowadzone przez Grzywniak, która jako pierwsza polska badaczka podjęła się tego zadania (Grzywniak, 2006, s. 48 i n.) $)^{8}$. W świetle powyższych faktów zarzuty stawiane przez Grabowską wydają się bezpodstawne'. Można jedynie stwierdzić, że metoda kinezjologii edukacyjnej wymaga jeszcze dalszych badań, które doprowadzą do dokładnego ustalenia jej podstaw naukowych. Za stosowaniem ćwiczeń Gimnastyki Mózgu przemawiają fakty. Są one proste do opanowania, nie pochłaniają wiele czasu i nie wymagają żadnych specjalnych akcesoriów. Zdecydowana większość dzieci szybko się ich uczy i czerpie z nich wiele radości. Łatwo je wkomponować w codzienny plan dnia nie tylko w szkole, czy w domu, ale również w miejscu pracy. Warto je wykorzystać jako wprowadzenie w stan gotowości do nauki, w celu integracji zmysłów, poprawienia refleksu i redukcji stresu (Rentschler, 2005, s. 100) ${ }^{10}$. 


\section{Bibliografia}

Grabowska A. (2008), Kinezjologia edukacyjna w świetle najnowszej wiedzy o mózgu, w: Korab K. (red.), Kinezjologia edukacyjna. Nauka, pseudonauka czy manipulacja?, Instytut Badań Edukacyjnych, Warszawa.

Grzywniak C. (2006), Kinezjologia edukacyjna - metoda wspomagania rozwoju i terapii psychomotorycznej, Wydawnictwo Naukowe Akademii Pedagogicznej, Kraków.

Hannaford C. (1995), Zmyślne ruchy, które doskonala umyst. Podstawy Kinezjologii Edukacyjnej, Oficyna Wydawnicza MEDYK, Warszawa.

Rentschler M. (2005), The Basics of Educational Kinesiology Volume, "Journal of Behavioral Optometry", nr 16 (4), s. 100.

www.centrumprogres.pl, dostęp: 14.12.2012.

\section{The influence of educational kinesiology practice on the effectiveness of vocabulary learning in the foreign language classroom}

\section{Summary}

Educational kinesiology, known as Brain Gym, is a new tendency in child development therapy. It consists in doing natural body movements in order to stimulate different spheres of a brain, integrate a central nervous system, improve coordination, concentration a learning process. A lot of controversy around the method was the reason to do research to prove educational kinesiology effectiveness. Experimental results are presented in this article.

Keywords: educational kinesiology, brain gym, brain plasticity, hand - eye coordination, effectiveness of vocabulary learning.

\footnotetext{
${ }^{1}$ Przywołana krytyka nie operuje analizami i wyjaśnieniami. Jest zbiorem ocen, bez argumentów. Nie wiem czy cytowana autorka poprzestaje na takiej analizie, czy robi to szczegółowiej, o czym autorki/rzy artykułu nie piszą. Są więc dwie drogi: albo w tym miejscu zostaną przytoczone argumenty krytyczne (jeśli są), albo ten wątek artykułu zostanie usunięty.

${ }^{2}$ Należy usunąć treść nad tabelą (schemat z SPSS) i zastąpić zapisem: Tabela 1. Statystyki opisowe badanych zmiennych. W tabeli nie może być symboli nie posiadających znaczenia, jak „P” w pierwszej kolumnie.

${ }^{3} \mathrm{JW}$.

${ }^{4} \mathrm{JW}$.

${ }^{5}$ Jw. lub można to włączyć jako ostatni wiersz poprzedniej tabeli.

${ }^{6}$ Brak przypisu.

${ }^{7}$ Proszę opisać te badania i wyniki.
} 
${ }^{8} \mathrm{Jw}$.

${ }^{9}$ Które zarzuty? Jeśli te opisane wyżej, nie trzeba się nimi zajmować. Jeśli były inne argumenty, np. merytoryczne, to wynik tego badania nie może ich zakwestionować. Ten wynik może jedynie wskazać skuteczność metody (nie daje podstawy do oceny, że zarzuty były bezpodstawne). A metoda może być skuteczna niezależnie od, nawet popartych badaniami, analiz krytycznych. Nie można zatem sądzić, że wynik tego badania obala argumenty przeciw tej metodzie.

${ }^{10}$ Celem artykułu była weryfikacja hipotezy, nie zaś propagowanie metody pracy dydaktycznej. Ten fragment należy usunąć. 